\title{
MARKET REACTION TO THE ADOPTION OF INTERNATIONAL FINANCIAL REPORTING STANDARD IN INDONESIA
}

\author{
Yen Sun; Evi Steelyana; Yoyo Cahyadi \\ Accounting and Finance Department, Faculty of Economic and Communication, BINUS University \\ Jln. K.H. Syahdan No.9, Palmerah, Jakarta Barat 11480 \\ ysun@binus.edu; evi.wiyarto@gmail.com; yoyo.cahyadi@gmail.com
}

\begin{abstract}
The aim of the study is to analyze the market's reaction on the adoption of International Financial Reporting Standard (IFRS) in Indonesia. Investor reaction will be perceived by the existence of abnormal return as well as the difference of trading volume. The analysis tool used is One-sample test to assess the existence of abnormal return and Paired Sample T-test to observe the difference trading volume 3 days before and after the announcement of financial report. The sample was constituted by 31 Indonesian companies randomly selected listed on LQ45 and have been impacted by the adoption of IFRS since 2011. The result shows that there is no abnormal return 3 days before and after the announcement of financial report. However, there is abnormal return on the day of announcement. Trading volume shows there is no market reaction to the IFRS adoption 3 days before and after the announcement
\end{abstract}

Keywords: market reaction, IFRS, abnormal return

\begin{abstract}
ABSTRAK
Tujuan dari penelitian ini adalah untuk menganalisis reaksi pasar terhadap adopsi International Financial Reporting Standard (IFRS) di Indonesia. Reaksi investor akan digambarkan dari adanya abnormal return serta perbedaan volume perdagangan. Alat analisis yang akan digunakan adalah uji One-sample test untuk menilai adanya abnormal return dan Paired Sample T-test untuk mengamati perbedaan dalam volume perdagangan 3 hari sebelum dan sesudah pengumuman laporan keuangan. Sampel terdiri dari 31 perusahaan Indonesia yang dipilih secara acak yang terdaftar di LQ45 dan telah terkena dampak adopsi IFRS sejak 2011. Hasil penelitian menunjukkan bahwa tidak ada abnormal return 3 hari sebelum dan sesudah pengumuman laporan keuangan. Akan tetapi, ada abnormal return pada hari pengumuman. Selanjutnya, volume perdagangan menunjukkan tidak ada reaksi pasar terhadap adopsi IFRS 3 hari sebelum dan sesudah pengumuman.
\end{abstract}

Kata kunci: market reaction, IFRS, abnormal return 


\section{INTRODUCTION}

Financial statement is a very important tool in order to understand and view the prospect of a company. A lot of user of financial statement depend their analysis in the validity of that report. Validity is related to the standard which is used to construct the financial statement. One of those standards is IFRS (International Financial Reporting Standard).

Indonesia has the convergence with the IFRS after long years using GAAP (Generally Accepted Accounting Standard). It certainly related to the global interests in order to enhance the information from financial statements of companies in Indonesia. IFRS Convergence is one of the agreements that have to be accepted by the government of Indonesia as a member of the G20 forum. It is a result from the G20 meeting of world leaders' forum in Washington DC, November 15, 2008. The principles of the G20 which were declared as follows: (1) Strengthening Transparency and Accountability, (2) Enhancing Sound Regulation, (3) Promoting Integrity in Financial Markets, (4) Reinforcing International Cooperation, (5) Reforming International Financial Institutions. By adopting these principles it is hoped that it will make financial condition in Indonesia easier to be recognized and will provoke investors to invest in Indonesia.

Accounting is the major business language in capital market. A proper international accounting standard system will support capital market function because financial statement is the main product of capital market mechanism. The effectiveness of financial statement as well as timelines, transparency, relevant and comparable is factors required by all stakeholders. From investment perspective, stakeholders need to compare financial information from one company to another which IFRS could support this requirement. International Accounting Standards, better known as International Financial Reporting Standards (IFRS), is a single reporting standard of high-quality accounting and financial reporting system. Financial reporting users can be easily comparing financial information inter-countries entities in different parts of the world.

Internationally, IFRS has been adopted by many countries, including the countries of the European Union, Africa, Asia, Latin America and Australia. In Asia, Hong Kong, Philippines and Singapore have also adopted it. Adopting IFRS means adopting global financial reporting language that would make a company can be understood by the global market. A company will have greater competitiveness when adopting IFRS in its financial statements.

With the adoption of IFRS as a single global accounting standard, Indonesian companies will be ready and able to transact, including mergers and acquisitions (M \& A) cross countries. IFRS is intended to be a single global accounting standard. Accounting industry in Indonesia will be supported and be more competitive at the global level. Based on those perspectives above, some Indonesia companies have already been doing IFRS implementation. Those companies were public companies and their financial statement could be easily accessed by investors in IDX.

As the relationship between financial statement and stock return is quite unique, some investors will react for any changes that are being made in financial reporting standard. In the bigger picture, capital market will be impacted by those changes. Market will react accordingly. At the end, it will impact to stock return and investor's reaction. It will be our focus in this research and this paper will discuss deeper about Market Reaction to the Adoption of International Financial Reporting Standard in Indonesian companies, especially after IFRS implementation.

The remainder of the paper is organized as follows. The next section, several relevant literatures have been reviewed. Moreover, section 3 contains research design, data and methodology. In section 4, the analysis and result is discussed; and conclusion in section 5. 


\section{Literature Review}

IFRS requires more transparency and disclosure of the company; some studies show that there is a connection between firms' cost of capital and the disclosure practices. Generally, the transparency of a company in its financial statements will decline the information asymmetry as well as the cost of equity (Botosan, 2006).

In accordance to the above notion, Armstrong states that IFRS adoption in Europe could have a positive reaction. It is expected that IFRS application will lowering information asymmetry between investor and company as a well as information risk and the cost of capital since IFRS application would result in higher quality financial reporting information (Armstrong et al. 2009). It is also believed that IFRS adoption will bring convergence benefits for example, lessen the cost of comparing company's financial performance across countries, and IFRS adoption is possible increasing the liquidity of European companies since IFRS adoption would facilitate European capital markets go for global competition. On the other hand, European's Investors could have a negative reaction towards IFRS adoption. This could possible happen if the investors assume that IFRS would produce inferior quality information of financial reporting. For instance, IFRS may not provide sufficient regional differences in economies that would trigger disparity in domestic accounting standards. Besides, Investors might have assumed that there is possible divergence in implementation of IFRS which trigger to the increase of implementation of opportunistic managerial decision when applying IFRS. Ultimately, Investors might have believed that the cost of alteration and execution of IFRS would outweigh the benefit. Proving those arguments, Armstrong conducts a study about the reaction of European equity market to 16 events related to the adoption of IFRS in Europe. The result of study suggests that the IFRS adoption carries net benefits to Europe market such as increases in information quality, lessens information asymmetry, more meticulous completion of the standards and convergence.

Almost similar study has been conducted by Latridis (2010) which focus his study on the adoption of the IFRS in the UK. The result of the study states that the accounting quality has been generally reinforced by the implementation of IFRS. The adoption of IFRS has reduced the scope of earnings management and produced more relevant accounting measures.

Karamanou and Nischiotis (2005) performs a study used a sample of 564 firms which adopt IAS voluntarily. The priority examinations are on the events prior and after the announcement of the adoption. The result shows that there is significant correlation between the firms' cost of capital and the adoption of IFRS. It explains that the increased disclosure of the firms led to a vast decline in the cost of capital.

Other researchers, Vazakidis and Athianos (2010), also study the investor's reaction to the adoption of IFRS in Greece using the market based-model. Ninety Greek companies which are listed in Athens Stock Exchange have been randomly selected. They use the Capital Asset Price Model which is inserted in a single regression in order to show the relation between the risk and the actual return. Afterwards, the market based-model has been constructed to obtain the aim of the study. The outcomes show that the switching of Greek Accounting to IFRS has influenced the valuation of the companies. While Klimczak (2011) conducts a similar research about market reaction to the adoption of IFRS in Poland. Abnormal returns have been assessed around annual consolidated report publication as well as the value relevance of earnings. The result shows that there is no unexpected information as a result of annual report publication either before, on, or after the adoption. Moreover, the value relevance delivers consistent earning coefficients for the unexpected earnings model for both adopters and non-adopters. Surprisingly, the adopters are even valued higher before the adoption, but not after the adoption. 
In accordance to the literature above, it is important to state that the company's cost of capital is the minimum return that a firm should attain with the aim of not to decline in its stock's market value. Furthermore, the estimation of company's cost of capital is essential for not only the valuation of the whole company but also the valuation of the company's issued stock.

\section{METHOD}

This research used purposive sampling method with several criteria as follows: (i) companies already listed in IDX in the last five years, (ii) companies including in LQ45 for the past one year (2011). LQ45 is an index which consists of 45 companies with high liquidity and market capitalization. (iii) IFRS have been implemented in those companies since 2011. There were 31 companies that have been selected randomly as presented on Table 1. To analyze the data, the statistical tool used was Paired Sample Test and One Sample Test.

Table 1 List of Companies

\begin{tabular}{lll}
\hline No. & IDX Code & Name of Company \\
\hline 1 & AALI & Astra Agro Lestari Tbk \\
2 & ANTM & Aneka Tambang (Persero) Tbk \\
3 & ASII & Astra Internasional Tbk \\
4 & ASRI & Alam Sutera Realty Tbk \\
5 & BBKP & Bank Bukopin Tbk \\
6 & BBTN & Bank Tabungan Negara (Persero) Tbk \\
7 & BDMN & Bank Danamon Indonesia Tbk \\
8 & BJBR & BPD Jawa Barat dan Banten Tbk \\
9 & BSDE & Bumi Serpong Damai Tbk \\
10 & CPIN & Charoes Pokphand Indonesia Tbk \\
11 & DOID & Delta Dunia Makmur Tbk \\
12 & ELTY & Bakrieland Development Tbk \\
13 & ENRG & Energi Mega Persada Tbk \\
14 & GGRM & Gudang Garam Tbk \\
15 & GJTL & Gajah Tunggal Tbk \\
16 & HRUM & Harum Energy Tbk \\
17 & ICBP & Indofood CBP Sukses Makmur Tbk \\
18 & INDF & Indofood Sukses Makmmur Tbk \\
19 & INDY & Indika Energi Tbk \\
20 & INTP & Indocement Tunggal Prakarsa Tbk \\
21 & ISAT & Indosat Tbk \\
22 & JSMR & Jasa Marga (Persero) Tbk \\
23 & KLBF & Kalbe Farma Tbk \\
24 & LPKR & Lippo Karawaci Tbk \\
25 & LSIP & PP London Sumatra Tbk \\
26 & PGAS & Perusahaan Gas Negara Tbk \\
27 & SMCB & Holcim Indonesia Tbk \\
28 & SMGR & Semen Gresik (Persero) Tbk \\
29 & TLKM & Telekomunikasi Indonesia Tbk \\
30 & UNSP & Bakrie Sumatra Plantation Tbk \\
31 & UNTR & United Tractors Tbk \\
\hline & & \\
\end{tabular}

The time period was 3 days before the announcement day $\left(27^{\text {th }}\right.$ March $-30^{\text {th }}$ March 2012) and 3 days after the announcement day $\left(2^{\text {nd }}\right.$ April $-4^{\text {th }}$ April 2012). To find the existence abnormal return, the calculation of expected return is needed. The basic that was used is CAPM 


$$
\mathrm{E}(\mathrm{RI})=\mathrm{RF}+\beta[\mathrm{E}(\mathrm{Rm})-\mathrm{RF}]
$$

The model accepted that the RF (risk free rate) can be derived from the BI rate, while Rm used the LQ45 Index return.

It is assumed that CAPM is able to describe the minimum expectation of investors for each share return (Botosan, 2006). Consequently, CAPM will lead investor to adjust their portfolios based on the risk profile of each company. It is assumed that if there is a reaction from investor, the actual return will differ from the expected return or abnormal return exist (abnormal return should be more than zero). Other indication to see the market reaction is the trading volume. There should be significant different of trading volume before and after the announcement of financial report.

Therefore some hypotheses are constructed as follows:

$\mathrm{H}_{1}$ : There is abnormal return during 3 days before the announcement day

$\mathrm{H}_{2}$ : There is abnormal return during 3 days after the announcement day

$\mathrm{H}_{3}$ : There is abnormal return on the announcement day

$\mathrm{H}_{4}$ : There is significant difference between trading volume 3 days before and after the announcement

\section{RESULTS AND ANALYSIS}

Descriptive statistic on abnormal return and trading volume is as shown in Table 2.

Table 2 Descriptive Statistics for Abnormal Return and Trading Volume

\begin{tabular}{l|r|r|r|r|r}
\hline \multicolumn{7}{|c|}{ Descriptive Statistics } \\
\hline & $N$ & \multicolumn{1}{c}{ Minimum } & Maximum & Mean & Std. Deviation \\
\hline CARmin3 & 31 & -0.0086 & 0.0307 & 0.0029 & 0.0099 \\
CARplus3 & 31 & -0.0201 & 0.1344 & 0.0011 & 0.0262 \\
CARotd & 31 & -0.0294 & 0.0693 & 0.0081 & 0.0190 \\
Volmin3 & 31 & $1,875,333.33$ & $162,281,000.00$ & $28,400,172.04$ & $42,156,944.70$ \\
Volplus3 & 31 & $630,166.67$ & $114,445,166.67$ & $19,132,521.51$ & $26,239,496.29$
\end{tabular}

Table 2 shows that the minimum CAR (cumulative abnormal return) is negative and the maximum of each CAR is almost equal to zero. The mean of CAR also shows a similar trend that equal to zero. Meanwhile, the mean of trading volume 3 days before the announcement is larger than the volume 3 days after the announcement.

$\mathrm{H}_{2}, \mathrm{H}_{3}$ :

Furthermore, the research uses statistical tool to carry out the result. Below is the result of $\mathrm{H}_{1}$,

Tabel 3 Summary CAR 3 days before, after, and on the day of the announcement

\begin{tabular}{lr}
\hline & \multicolumn{1}{c}{$\boldsymbol{p}$-value } \\
\hline CAR min 3 & 0.114 \\
CAR plus 3 & 0.815 \\
CAR on the day & 0.025 \\
\hline
\end{tabular}


The result shows that there is no abnormal return 3 days before and after the announcement of financial report since the significance (2-tailed) level are over $5 \%$.

Meanwhile, the table below shows the result of $\mathrm{H}_{3}$ that abnormal return exists on the day of the announcement.

Table 4 Trading volume difference 3 days before and after the announcement

$$
\begin{array}{ll}
\text { Paired Sample T-test pvalue } & \\
\hline \text { Trading Volume } & 0.072
\end{array}
$$

It is shown that the significance (2-tailed) levels are over 5\%, which means there is no significant different on trading volume 3 days before and after the announcement.

The possible explanation that can be drawn from the analysis above is the reaction to the adoption of IFRS only occurs on the day of the announcement of financial report.

\section{CONCLUSION}

The adoption of IFRS to Indonesian company is expected to bring more qualified information to all stakeholders including the investor. The study provides the market reaction to the adoption of IFRS by using the Capital Asset Pricing Model to depict the association of risk and the actual price. The study tries to depict the reaction of investor during 3 days before and after the announcement of financial report as well as on the day of the announcement through the existence of abnormal return and the difference of trading volume during that period.

The result suggests that there is no abnormal return during 3 days before and after the announcement of financial report. However, the abnormal return is captured on the day of announcement. Trading volume could not prove the existence of market reaction. Nonetheless, since the study is limited in its sample and model, further studies will be necessary to be expanded by using more samples and sophisticated model.

\section{REFERENCES}

Armstrong, S., Barth, E., Jagolinzer, A. and Riedl, E. (2009). Market reaction to the adoption of I.F.R.S in Europe. Working Paper Series, Accounting Review forthcoming.

Botosan, C. (2006). Disclosure and the cost of capital: What do we know. Account. Bus. Res, 36, 3140.

Karamanou, I. \& Nischiotis, G. (2005). The valuation effects of firms voluntary adoption of international accounting standards. Working Paper. University of Cyprus.

Klimczak, K. M. (2011). Market reaction to mandatory IFRS adoption: Evidence from Poland. Accounting and Management Information Systems, 10(2), 228-248. 
Latridis, G. (2010). International Financial Reporting Standards and the quality of Financial statement information. International Review of Financial Analysis, 19, 193-204

Vazakidis, A. \& Athianos, S. (2010). Measuring Investors' Reaction to the Adoption of International Financial Reporting Standards in Greece, Using a Market-Based Model. American Journal of Economics and Business Administration, 2(1), 103-112. 